\title{
PERKAWINAN BEDA AGAMA DALAM PARADIGMA SOSIOLOGICAL JURISPRUDENCE
}

\author{
Roni Efendi \\ Institut Agama Islam Negeri Batusangkar, roniefendi@iainbatusangkar.ac.id
}

\begin{tabular}{|l|l|l|}
\hline Diterima: 16 Januari 2020 & Direvisi : 07 Juli 2020 & Diterbitkan: 09 Juli 2020 \\
\hline
\end{tabular}

\begin{abstract}
The promulgation of the Marriage Law is as a tool of social engineering or an instrument to regulate the community and as a guideline for the community to carry out a marriage. So those friendships that are carried out are not based on or violate religious law contained in the Marriage Law deemed invalid, one of which is interfaith marriages. The diversity of Indonesian society has been regulated by several provisions and diverse institutions, moreover related to the requirements of marriage. The occurrence of social facts in the form of violation of the regulations of marriage in the way of interfaith marriages according to the Sociological jurisprudence school is the result of proper gradation, morals which have been the basis for the formation of law. If ethics or morals become evil, it will result in bad behavior, both the behavior of individuals, groups and state officials.
\end{abstract}

Keywords: Mariage, Deifferent Religion, Sociological Jurisprudence.

\begin{abstract}
Abstrak
Diundangkannya UU Perkawinan adalah sebagai a tool of social engineering atau instrumen untuk mengatur masyarakat dan sebagai pedoman bagi masyarakat untuk melaksanakan sutu perkawinan. Sehingga perkawinan yang dilaksanakan tidak berdasarkan atau menyalabi bukum agama yang terkandung dalam UU Perkawinan dianggap tidak sah, salah satunya adalah pernikahan beda agama. Beragamnya masyarakat Indonesia telah diatur dengan ketentuan yang beragam dan institusi yang beragam pula apalagi terkait dengan kenetuan perkawinan. Terjadiny a fakta sosial dalam bentuk pelaggaran terbadap ketentuanketentuan perkawinan dalam wujud perkawinan beda agama menurut aliran Sosiological jurisprudence merupakan akibat dari terjadinya gradasi moral, moral yang selama ini menjadi dasar terbentuknya bukum. Jika etika atau moral menjadi buruk, maka akan berakibat pada prilaku-prilaku buruk, baik prilaku perorangan, kelompok maupun pejabat negara.
\end{abstract}

Kata Kunci : Perkawinan, Beda Agama, Sosiological Jurisprudence .

\section{PENDAHULUAN}

Perkawinan, sebagaimana dinyatakan dalam Pasal 1 Undang-Undang Nomor 1 Tahun 1974 tentang Perkawinan (selanjutnya ditulis UU Perkawinan) merupakan ikatan lahir batin antara seorang pria dengan seorang wanita sebagai suami istri dengan tujuan untuk membentuk keluarga (rumah tangga) yang bahagia dan kekal berdasarkan Ketuhanan Yang Maha Esa. ${ }^{1}$ Berdasarkan ketentuan

1 Pasal 1 Undang-Undang Nomor 1 Tahun 1974 tentang Perkawinan. tersebut, menurut pendapat Lili Rasjidi sebagaimana penulis kutip dari Sri Wahyuni dapat dinyatakan bahwa ikatan lahir batin merupakan hal penting dari suatu perkawinan. Selanjutnya, perkawinan juga dipandang sebagai suatu usaha untuk mewujudkan kehidupan yang bahagia dengan landasan kepada Tuhan Yang Maha Esa. ${ }^{2}$

Ikatan lahir batin dari suatu perkawinan itu tidak hanya cukup dengan 
adanya ikatan lahir atau ikatan batin saja, tetapi harus kedua-duanya. Suatu ikatan lahir adalah ikatan yang dapat dilihat, yaitu adanya hubungan hukum antara seorang pria dan wanita untuk hidup bersama sebagai suami istri dan dapat disebut juga dengan ikatan formal. Sementara, hubungan batin merupakan hubungan yang tidak formil, suatu ikatan yang tidak dapat dilihat, tetapi harus ada karena tanpa adanya ikatan batin, ikatan lahir menjadi rapuh. ${ }^{3}$

Berdasarkan pengertian perkawinan tersebut, dapat dikatakan bahwa perkawinan mempunyai aspek yuridis, sosial dan religius. Aspek yuridis terdapat dalam ikatan lahir atau formal yang merupakan suatu hubungan hukum antara suami dan istri. Sementara hubungan yang mengikat diri mereka dan orang lain atau suatu masyarakat merupakan aspek sosial dari perkawinan. Adapun aspek religius yaitu dengan adanya klausul berdasarkan Ketuhanan yang Maha Esa, sebagai dasar pembentukan keluarga yang bahagia dan kekal. Hal ini tentu sesuai dengan landasan filosofis bangsa Indonesia dalam sila pertama yaitu Ketuhana Yang Maha Esa, maka perkawinan mempunyai hubungan yang erat sekali dengan agama atau kerohaian sehingga perkawinan bukan saja unsur lahir atau jasmani, tetapi unsur batin atau rohani juga mempunyai peranan penting. ${ }^{4}$

Aspek religius ini juga terdapat dalam Pasal-Pasal lain, seperti dalam syarat syahnya perkawinan serta larangan-larangan perkawinan. Dalam Pasal 2 ayat (1) UU Perkawinan disebutkan bahwa perkawinan adalah sah, apabila dilakukan menurut hukum masing-masing agamanya dan kepercayaannya itu. Adapun dalam larangan perkawinan, Pasal 8 huruf $\mathrm{f}$ menyatakan bahwa perkawinan dilarang antara dua orang yang mempunyai hubungan yang oleh agamanya dilarang atau peraturan lain yang berlaku dilarang kawin. ${ }^{5}$
Pasal-Pasal tersebut di atas telah memeberikan garis demarkasi yang jelas bahwa perkawinan di Indonesia adalah perkawinan berdasarkan hukum agama, sehingga perkawinan yang dilaksanakan tidak berdasarkan atau menyalahi hukum agama dianggap tidak sah. Pasal-pasal tersebut di atas berfungsi sebagai alat untuk mengatur masyarakat atau a tool of social engineering. Sehingga jika masyarakat berpegang pada ketentuan perkawinan yang di dalamnya mencakup aspek yuridis, sosial dan religius maka akan dapat mencapai tujuan suatu perkawinan, yaitu membentuk keluarga sakinah, mawaddah dan warrahmah.

Namun, seiring dengan berkembangnya masyarakat, permasalahan yang terjadi juga semakin kompleks. Satu di antaranya adalah berkaitan dengan perkawinan, hingga hari ini tersiar diberbagai media baik cetak, elektronik maupun sosial media bahwa terjadinya perkawinan yang dianggap problematik dalam kehidupan masyarakat yaitu perkawinan beda agama. Perkawinan beda agama merupakan perkawinan yang dilakukan antara seorang laki-laki dan perempuan yang memiliki perbedaan keyakinan (agama), atau sering disebut dengan perkawinan beda agama. Perkawinan beda agama di sini berbeda dengan perkawinan campuran, namun tidak tertutup kemungkinan perkawinan campuran juga sebagai salah satu faktor terjadinya perkawinan beda agama.

Perkawinan beda agama terjadi sebagai realitas yang tidak dapat dipungkiri dalam masyarakat Indonesia, banyak kasuskasus yang terjadi tentang pernikahan beda agama oleh wanita muslim dan menikah dengan laki-laki non muslim yang pernah terjadi di Indonesia di antaranya Nurul Arifin (Muslim) menikah dengan Mayong (Katolik), Yuni Shara (Muslim) yang menikah dengan Hendri Siahaan

\footnotetext{
${ }^{3}$ K.Wantik Saleh, Hukum Perkawinan Indonesia, Jakarta, Ghalia, 1992, 14-15.
}

\footnotetext{
${ }^{4}$ Sri Wahyuni, Op.Cit, 2.

${ }^{5}$ Ibid.
} 
(Kristen) dan masih banyak lagi yang lainnya. ${ }^{6}$ Hal ini terjadi salah satu alasannya terkait dengan pasal 27, Pasal 28C Undang-Undang Dasar Negara Republik Indonesia jo Pasal 11 Undang-Undang Nomor 39 Tahun 1999 tentang Hak Asasi Manusia. Namun, bukan berarti dengan adanya hak yang diproteksi oleh konstitusi dapat melakukan perkawinan beda agama sebagai perwujudan dari hak asasi manusia. UUD 1945 merupakan Grund Norm yang mempunyai peraturan-peraturan turunan di bawahnya seperti undang-undang perkawinan sebagai aturan turunan yang berkaitan dengan ketentuan perkawinan sebagai salah satu hak warga negara Indonesia.

Fakta hukum yang terjadi bahwa perkawinan antar agama tersebut merupakan suatu wujud ketidakpatuhan terhadap undangundang, hal tersebut dapat dicegah apabila pemerintah tegas dan menghilangkan sikap ambivalensi dalam perkawinan beda agama. Hal ini terlihat dalam praktek apabila perkawinan tidak dapat dilakukan di Kantor Urusan Agama, dapat dilakukan di Kantor Catatan Sipil dan menganggap sah perkawinan antar agama yang di lakukan di luar negeri.

Hal ini akan menimbulkan multy tafsir terhadap masih adanya kasus perkawinan antar agama tersebut. Terjadinya kasus seperti ini apakah memang benar-benar tidak tegasnya peraturan-peraturan tentang hukum perkawinan, atau dapat dikatakan bahwa hukum yang ada saat ini tidak sesuai dengan kebutuhan atau hukum yang hidup dalam masyarakat. Juga tidak tertutup kemungkinan bahwa hukum yang ada sudah tepat dan dapat dikembangkan lagi untuk dijadikan sebagai instrumen perubahan sosial yakni hukum

\footnotetext{
${ }^{6}$ Meilisa Fitri Harahap, Penyelesaian Perceraian Beda Agama di Indonesia, Skripsi, Padang, Fakultas Hukum Universitas Andalas, 2011, 3.

Mochtar Kusumaatmaja, Hukum, Kemasyarakatan, dan Pembinaan Hukum Nasional, Bandung, Binacipta, 1976, lampiran 1.
}

sebagai sarana yang penting untuk memelihara ketertiban, sehingga dapat menjadi ruang gerak bagi perubahan sosial kemasyarakatan. Dalam hal ini hukum dapat tampil kedepan menunjukkan arah dan memberi jalan bagi perubahan. $^{7}$

Aliran sosiological jurisprudence melihat masyarakat dari pendekatan hukumnya yang salah satu rinciannya meliputi fungsi dari hukum terhadap masyarakat. Yakni fungsi hukum sebagai kerangka ideologis perubahan struktur dan kultur masayarakat. ${ }^{8}$ Dalam paradigam sosiological jurisprudence yang melihat fungsi hukum dari hukum terhadap masyarakat dengan spesifikasi fungsi hukum sebagai kerangka ideologis perubahan struktur dan kultur masyarakat, maka dapat ditanggapi struktur dan kultur yang dimaksud menyangkut sebuah proses transformasi struktur dan kultur yang tidak mudah. ${ }^{9}$ Terkait dengan persolan pernikahan beda agama, aliran sosiological jurisprudence dapat memberikan jawaban tersendiri terhadap fenomena masyarakat Indonesia ini. Hal tersebut akan menarik untuk dibahas lebih mendalam dalam sebuah artikel yang berjudul "Perkawinan Beda Agama Dalam Paradigma Aliran Sosiological Jurisprudence".

\section{METODE PENELITIAN}

Penulis menggunakan metode penelitian hukum normatif, yang mencakup tentang asas-asas hukum. Selain itu penelitian ini juga mengkaji dan meneliti peraturan perundang-undangan. ${ }^{10}$ Yakni peraturan perundang-undangan, meta norma yang berasal dari kajian filsafat dan teori hukum. Sehingga ditemukan masalah dan solusi fundamental terkair dengan plagiat sebagai bentuk

\footnotetext{
${ }^{8}$ Erman Radjaguguk, Hukum dan Masyarakat, Jakarta, Bina Aksara, 1983, 72.

${ }^{9}$ Sumaryati Hartono, Politik Hukum Menuju Satu Sistem Hukum Nasional, Bandung, Alumni, 1991, 78.

10 Soerjono Soekanto, Kriminologi: Suatu Pengantar, Cetakan Pertama, Jakarta, Ghalia Indonesia, 1981, . 15 .
} 
pelanggaran akademik dalam paradigma teori property. Penelitian hukum normatif ini akan bertitik tolak pada bahan pustaka atau data sekunder, dengan cakupan bahan hukum primer, sekunder dan tersier. Metode penelitian hukum normatif merupakan metode atau cara yang dipergunakan di dalam penelitian hukum yang dilakukan dengan cara meneliti bahan pustaka. ${ }^{11}$ Dengan kata lain penelitian ini merupakan penelitian kepustakaan (library reseach) yaitu penelitian ini dilakukan dengan membaca karya-karya yang relevan dengan objek kajian kemudian memuat kajian tentang penelitian. ${ }^{12}$

\section{PERKAWINAN BEDA AGAMA DALAM PARADIGMA ALIRAN SOSIOLOGICAL JURISPRUDENCE KETIDAKPATUHAN TERHADAP PERKAWINAN}

Aliran Sosiological Jurisprudence ini tumbuh dan berkembang di Amerika Serikat oleh seorang pionernya Roscoe Pund melalui karya besarnya yang berjudul Scope and Purpose of Sosiological Jurisprudence pada tahun 1912. Inti dari aliran ini terletak pada penekakan bahwa hukum yang baik adalah yang sesuai dengan hukum yang hidup di dalam masyarakat. Sosiological Jurisprudence berbeda dengan sosiologi hukum. Sosiological Jurisprudence merupakan suatu mazhab dalam filsafat hukum yang mempelajari pengaruh timbal balik antara hukum dan masyarakat serta sebaliknya, sementara sosiologi hukum mempelajari pengaruh di dalam masyarakat kepada hukum dan sejauh mana gejala-gejala yang ada di

11 Soerjono Soekanto dan Sri Mamudji, Penelitian Hukum Normatif Suatu Tinjauan Singkat, Cetakan ke 11, Jakarta, PT Raja Grafindo Persada, 2009, 13-14.

12 Mestika Zed, Metode Penelitian Kepustakaan, Jakarta, Yayasan Obor Indonesia, 2007, 3.

${ }^{13}$ Lili Rasjidi dab B. Arief Sidharta, Filsafat Hukum : Mazhab dan Refleksinya, Bandung, CV Remadja Karya, 1989, 84. samping itu juga diselidiki pengaruh hukum terhadap masyarakat. ${ }^{13}$

Aliran ini lahir dari proses dialektika antara yang sebagai tesis adalah aliran hukum positif dan yang sebagai antitesis adalah mazhab sejarah yang kemudian menghasilkan sintesis berupa Sosiological Jurisprudence. Aliran hukum positif memandang bahwa tiada hukum kecuali perintah yang diberikan oleh penguasa (law is command of lawgiver), sebaliknya mazhab sejarah menyatakan bahwa hukum itu timbul dan berkembang bersama dengan masyarakat. Aliran hukum positif lebih mementingkan akal, sementara mazhab sejarah lebih mementingkan pengalaman, dan Sosiological Jurisprudence menganggap keduanya sama penting. Sintesis Sosiological Jurisprudence dimaksudkan berusaha menekankan adanya sisi hukum dan sisi masyarakat secara bersamaan. ${ }^{14}$

Roscoe Pound berpendapat bahwa hukum harus dilihat sebagai suatu lembaga kemasyarakatan yang berfungsi untuk memenuhi kebutuhan-kebutuhan sosial. Selain itu dianjurkan untuk mempelajari hukum sebagai suatu proses (law in action) yang dibedakan dengan hukum tertulis (law in the books). Salah satu pendapat Pound adalah bahwa hukum itu merupakan a toll of engneering (hukum sebagai pranata sosial atau hukum sebagai alat untuk membangun masyarakat). ${ }^{15}$

Menurut Pound, pada saat terjadi imbangan antara kepentingan dalam masyarakat maka yang akan muncul adalah kemajuan hukum. Roscoe Pound mengadakan tiga penggolongan utama terhadap kepentingan-kepentingan yang dilindungi oleh hukum, yaitu :

14 Darji Darmodiharjo dan Shidarta, PokokPokok Filsafat Hukum (Apa dan Bagaimana Filsafat Hukum Indonesia), Jakarta, PT. Gramedia Pustaka Utama, 1995, 110-111.

15 Astim Riyanto, Filsafat Hukum, Bandung, YAPEMDO, 2003, 405. 
1. Public Interest, yang meliputi kepentingan negara sebagai badan hukum dalam tugasnya memelihara hakikat negara dan kepentingan negara sebagai penjaga dari kepentingan sosial.

2. Kepentingan orang perorangan yang diberikan oleh Pound menjadi tiga kepentingan lagi, kepentingan pribadi (fisik, kebebasan kemauan, kehormatan, privacy, kepercayaan dan pendapat), kepentingankepentingan dalam rumahtangga, dan penetingan mengenai harta benda.

3. Kepentingan Sosial yang meliputi keamanan umum, kemanan dari institusi-institusi sosial, moral umum, pengamanan sumbersumber daya sosial, kemajuan sosial dan kehidupan individual. ${ }^{16}$

Toko signifikan berikutnya dari aliran ini ada pada pandangan-pandangan Eugen Ehrlich, Eugen Ehrlich sangat menentang adanya kekuasaan tak terbatas yang diberikan kepada penguasa karena dipandangnya akan memberikan sarana kepada penguasan untuk melakukan penyimpangan hukum terhadap masyarakat. Oleh karena itu, harus ada keseimbangan antara kepentingan penguasa dan kepentingan masyarakat. Kekuasaan tak terbatas dilakukan oleh negara terhadap masyarakat dalam hal spesifik elit kelompok sosial. $^{17}$

Secara konsekuen Ehrlich beranggapan bahwa mereka yag berperan sebagai pihak yang mengembangkan sistem hukum harus mempunyai hubungan erat dengan nilai-nilai yang dianut oleh masyarakat. Kesadaran itu harus ada pada setiap anggota profesi hukum yang bertugas mengembangkan hukum yang hidup dan menentukan ruang lingkup hukum positif dengan hukum yang hidup. ${ }^{18}$

Titik berat aliran Sosiological Jurisprdence terletak pada kenyataan sosial yang dapat menjadi kenyataan hukum (fakta hukum). Fakta-fakta hukum yang mendasari semua hukum adalah kebiasaan, dominasi, pemilikan dan pernyataan kemauan. Keempat faktor ini masing-masing melaksanakan hubunganhubungan hukum, atau melakukan pengawasan, memberlakunya, menghalanginya atau tidak memberlakukannya. ${ }^{19}$

Tetapi tidak menutup kemungkinan bahwa hukum akan menjadi instrumen perubahan sosial yakni hukum sebagai sarana yang penting untuk memelihara ketertiban harus dikembangkan, sehingga dapat memberi ruang gerak bagi perubahapan sosialkemasyarakatan. Dalam hal ini hukum dapat tampil kedepan menunjukkan arah dan memberi perubahan. ${ }^{20}$

Pada akhirnya dapat disimpulkan bahwa aliran ini memandang hukum sebagai kenyataan dan bukan sebagai kaidah. Hukum baru dapat disebut hukum jika ada jaminan eksternal bahwa aturan itu dapat dipaksakan melalui paksaan fisik maupun psikologis. Para penggagas aliran ini begitu menyadari bahwa pada prinsipnya Sosiological Jurisprdence begitu memberi penekanan terhadap pentingnya keseimbangan antara hukum formal dengan hukum yang hidup dalam masyarakat. Perkembangan hukum sesuai dengan perkembangan masyarakat menurut aliran ini gerakannya mulai dari irasional menuju rasional. $^{21}$

Sosiological Jurisprudence memberikan penekakan bahwa hukum yang baik adalah yang

19 W. Friedmann, Teori dan Filsafat Hukum, Idealisme Filosofis dan Problema Keadilan, Susunan Kedua, Jakarta, Rajawali Pers, 1994, 105.

${ }^{20}$ Mochtar Kusuma Atmaja, Loc.Cit.

${ }_{21}$ Muhammad Erwin, Filsafat Hukum Refleksi Kritis Terbadap Hukum, Jakarta, Rajawali Pers, 2013, 200. 
sesuai dengan hukum yang hidup di dalam masyarakat serta hukum itu merupakan a toll of engneering (hukum sebagai pranata sosial atau hukum sebagai alat untuk membangun masyarakat). Dapat dilihat bahwa korelasinya fakta sosial yang menjadi sorotan utama dalam artikel ini yaitu terjadinya perkawinan beda agama di kalangan masyarakat Indonesia. Masyarakat pada hakikatnya telah terikat dengan nilai-nilai dan norma-norma yang berkembang di tengah-tengah masyarakat, nilai dan norma tersebut tumbuh dan berkembang sesuai dengan hukum yang hidup di tengahtengah masyarakat. Living law sebagai wujud dari nilai dan norma yang hidup dan sesuai dengan masyarakat dengan sangat tegas memberikan aturan dan tuntunan kepada setiap masyarakat khususnya dalam hal perkawinan.

Aturan tersebut kemudian disintesiskan dalam wujud aturan tertulis yang bertujuan untuk memberikan kepastian hukum maka living law diakomodir dalam bentuk peraturan perundang-undangan yang mengatur tentang perkawinan. Di mana dalam peraturan perundang-undangan sudah sangat jelas ketentuan-ketentuan yang berkaitan dengan perkawinan bagi masyarakat Indonesia, yaitu bagi mereka yang beragam Islam, maka mereka harus patuh dan tunduk dengan ketentuan yang ada yakni UU Perkawinan, kemudian Peraturan Pemerintah No 9 Tahun 1975 sebagai peraturan pelaksana dari Undang-Undang Perkawinan dan Instruksi Presiden Nomor 1 Tahun 1991 tentang Kompilasi Hukum Islam. Sementara bagi mereka yang beragama selain Islam, maka mereka harus patuh dan tunduk kepada Kitab Undang-Undang Hukum Perdata khususnya bab yang mengatur tentang perkawinan.

Karena apabila kita mengacu kepada Sosiologigal Jurisprudence, dengan maksud utamanya adalah hukum sebagai alat untuk mengatur masyarakat dengan cara membuat ketentuan hukum berdasarkan kultur masyarakat dan membangun institusi yang beragam juga dengan tujuan untuk mengakomodir setiap kebutuhan masyarakat. Dalam fenomena sosial yang menjadi fokus tulisan ini, aliran Sosiological Jurisprudence menurut penulis sudah relefan dengan penegakkan hukum di Indonesia, yakni telah adanya aturan hukum dan institusi yang beragam sesuai dengan keberagaman masyarakat Indonesia itu sendiri. Maksudnya khusus dalam hukum perkawinan, bagi masyarakat yang berkeyakinan muslim mereka harus tunduk kepada undang-undang perkawinan dan berbagai peraturan pelaksananya, institusi yang akan menyelenggarakan juga sudah beragam seperti Kantor Urusan Agama dan Pengadilan Agama. Bagi mereka yang beragama Non Muslim, maka mereka akan tunduk dengan hukum perdata konvensional dalam hal ini Kitab Undang-undang Hukum Perdata sebagai sumber hukum materil perkawinan, kantor Catatan Sipil sebagai institusi yang akan memfasilitasi yang berkaitan dengan hal itu dan pada akhirnya nanti apabila terjadi perselisihan (cerai) akan diselesaikan di pengadilan Negeri yang mempunyai kompetensi absolut dalam persoalan tersebut.

Peraturan-peraturan tersebut di atas dalam aliran sosiological jurisprudence dikatakan hukum sebagai pranata sosial atau hukum sebagai alat untuk membangun masyarakat. Dengan demikian hakikat utama dari aliran ini telah diakomodir oleh sistem hukum di Indonesia. Namun dalam realisasinya masih terdapat pelanggaran peraturan seperti fakta sosial yang telah penulis jelaskan di atas maka bukan berarti tidak tercapainya tujuan aliran sosiological jurisprudence sebagai sintesis dari aliran positifis sebagai thesis dan aliran hukum alam sebagai antitetisnya. Menurut Penulis terjadinya pelangaran ketentuan perkawinan di Indonesia oleh mereka yang melakukan perkawinan beda agama dalam paradigma Sosiological Jurisprudence dikarenakan ketidakpatuhan mereka tehadap norma, nilai-nilai dan etika hukum. 
Membahas tentang ketidak patuhan masyarakat terhadap peraturan itu berarti membahas posisi manusia di dalam hukum di Indonesia. Kita bertanya kepada diri kita sendiri tentang perhatian yang telah kita berikan terhadap manusia di Indonesia dalam pengaturan hukum di negeri ini, termasuk penggunaan doktrin dan instansi yang berhubungan dengan hukum. Apapun yang dilakukan oleh hukum, ia tidak dapat mengabaikan bahwa manusia yang berada di pusatnya, sehingga kita berkesimpulan bahwa "hukum untuk manusia" dan bukan sebaliknya. ${ }^{22}$

Dalam membicarakan mengenai posisi manusia dalam hukum dan kedudukannya yang central, niscaya pemahaman tentang sifat-sifat manusia yang menjadi subjek dalam hukum itu berada diurutan pertama. Arsitektur serta design hukum yang dibangun harus bisa mewadai sifatsifat manusia sebagai subjeknya itu. Di sisi lain kendati manusia di dunia secara biologisfisiologis adalah sama, tetapi secara sosial yang berbeda-beda. Hal itu niscaya berpengaruh kuat terhadap institusi yang dipakainya, termasuk hukum. Artinya untuk sifat dan karakteristik sosial yang berbeda, dibutuhkan institusi yang berbeda pula. ${ }^{23}$

Dalam kaitanya dengan peraturan perkawinan, bangsa Indonesia telah memberikan pengaturan dan institusi yang berbeda-beda pula. Namun sekiranya masih terjadi ketidakpatuhan masyarakat terhadap ketentuan terhadap hukum perkawinan itu dikarenakan tidak adanya kepatuhan masyarakat terhadap moral, nilai dan etika hukum.

Pengertian moralitas hampir sama dengan pengertian etika, moralitas berasal dari kata latin mos yang bentuk jamaknya mores berarti adat istiadat atau kebiasaan. Jadi dalam pengertian pertamanya yaitu pengertian harfiahnya, moralitas dan etika sama-sama berarti sistem nilai tentang bagaimana manusia harus hidup baik sebagai manusia yang telah diinstitusionalisasikan dalam sebuah adat istiadat kebiasaan yang kemudian terwujud dalam pola prilaku yang ajek dan terulang dalam kurun waktu yang lama sebagaimana layaknya sebuah kebiasaan. ${ }^{24}$ Jadi selain substansi hukum yang harus baik bagi masyarakat Indonesia, masyarakat juga harus memiliki norma, nilai serta etika dalam mematuhi peraturan yang ada dalam substansi hukum terebut.

\section{KESIMPULAN}

Sosiological

jurisprudence

yang

notabenenya merupakan sintesis dari hukum positif (tesis) dan antitesis dari mazhab sejarah pada dasarnya telah memberikan pengaturan sesuai dengan porsinya masing-masing. Beragamnya masyarakat Indonesia telah diatur dengan ketentuan yang beragam dan institusi yang beragam pula apalagi terkait dengan kenetuan perkawinan. Terjadinya fakta sosial dalam bentuk pelaggaran terhadap ketentuanketentuan perkawinan dalam wujud perkawinan beda agama menurut aliran Sosiological jurisprudence merupakan akibat dari terjadinya gradasi moral, moral yang selama ini menjadi dasar terbentuknya hukum. Jika etika atau moral menjadi buruk, maka akan berakibat pada prilaku-prilaku buruk, baik prilaku perorangan, kelompok maupun pejabat negara.
22 Satjipto Raharjo, Sisi-Sisi Lain Hukum di Indonesia, Jakarta, Kompas, 2003, 34. ${ }^{23} \mathrm{Ibid}$
${ }^{24}$ Satjipto Raharjo, Membedab Hukum Progresif, Jakarta, Kompas, 2006, 215.q 


\section{DAFTAR KEPUSTAKAAN}

Astim Riyanto, Filsafat Hukum, Bandung, YAPEMDO, 2003.

Darji Darmodiharjo dan Shidarta, Pokok-Pokok Filsafat Hukum (Apa dan Bagaimana Filsafat Hukum Indonesia), Jakarta, PT. Gramedia Pustaka Utama, 1995.

Erman Radjaguguk, Hukum dan Masyarakat, Jakarta, Bina Aksara, 1983.

K.Wantik Saleh, Hukum Perkawinan Indonesia, Jakarta, Ghalia, 1992.

Mochtar Kusumaatmaja, Hukum, Kemasyarakatan, dan Pembinaan Hukum Nasional, Bandung, Binacipta, 1976.

Lili Rasjidi dab B. Arief Sidharta, Filsafat Hukum : Mað̧hab dan Refleksinya, Bandung, CV Remadja Karya, 1989.

Mestika Zed, Metode Penelitian Kepustakaan, Jakarta, Yayasan Obor Indonesia, 2007.

Meilisa Fitri Harahap, Penyelesaian Perceraian Beda Agama di Inonesia, Skripsi, Padang, Fakultas Hukum Universitas Andalas, 2011.

Muhammad Erwin, Filsafat Hukum Refleksi Kritis Terhadap Hukum, Jakarta, Rajawali Pers, 2013.

Satjipto Raharjo, Ilmu Hukum, Bandung, Citra Aditya Bhakti, 2000.

, Sisi-Sisi Lain Hukum di Indonesia, Jakarta, Kompas, 2003. , Membedah Hukum Progresif, Jakarta, Kompas, 2006.

Soerjono Soekanto, Kriminologi: Suatu Pengantar, Cetakan Pertama, Jakarta, Ghalia Indonesia, 1981. , Perspektif Teoritis Studi Hukum Dalam Masyarakat, Jakarta, Rajawali Pers, 1985. , dan Sri Mamudji, Penelitian Hukum Normatif Suatu Tinjauan Singkat, Cetakan ke 11, Jakarta, PT Raja Grafindo Persada, 2009.

Sri Wahyuni, Nikah Beda Agama Kenapa Harus Ke Luar Negeri?, Tanggerang, PT Pustaka Alvabet, 2016.

Sumaryati Hartono, Politik. Hukum Menuju Satu Sistem Hukum Nasional, Bandung, Alumni, 1991.

Theo Huijbers, Filsafat Hukum Dalam Lintas Sejarah, Yogyakarta, Kanisius, 1982.

W. Friedmann, Teori dan Filsafat Hukum, Idealisme Filosofis dan Problema Keadilan, Susunan Kedua, Jakarta, Rajawali Pers, 1994. 